American Journal of Applied Sciences 4 (1): 14-18, 2007

ISSN 1546-9239

(C) 2007 Science Publications

\title{
The Role of Quality Control and Everyone's Participation in Japan to Prevent Pollution During Last Five Decades
}

\author{
${ }^{1}$ Mohammed Matouq, ${ }^{2}$ Nasir Kloub and ${ }^{3}$ Kazue Inoue \\ ${ }^{1}$ Faculty of Engineering Technology, Chemical Engineering Department \\ ${ }^{2}$ Mechanical Engineering Department, Al-Balqa Applied University, \\ Amman, POBox 4486, 11131 Jordan \\ ${ }^{3}$ International Development Engineering Society, Tokyo, Japan
}

\begin{abstract}
Economic Growth in Japan after World War II was very remarkable and products from its manufacturing industry were widely accepted in the world market after productivity and quality of them were tremendously improved. On the other hand, Japan soon found itself in severe environmental deterioration, due to not being paid any attention to environment. However, that pollution from industry was removed rather promptly with help of quality control and everyone's participation. Japanese economic growth depends much on the quality of products, which was improved initially by what was known by Statistical Quality Control (SQC), widely used in the U.S.A. Later on SQC was transformed to Total Quality Control (TQC) with small group activities named QC Circles by Japanese and with some modifications and/or from different approaches, Total Quality Management (TQM), Total Productive Maintenance (TPM), KAIZEN (improvement) and so on were created. These approaches were introduced and widely used among industries and other sectors in Japan as well as in other countries of the world. The basic philosophy which leads these approaches to success was everyone's participation and continuous efforts for improvement. The aim of these methods were at first to improve quality and productivity, but emission of hazardous material was reduced quickly and environmental circumstances inside and outside of manufacturing sites were drastically improved as well by these activities. As the result, most of Japanese products are environment-friendly from manufacturing origin and have excellent Quality at the same time. In this paper, the philosophies of these TQC, TPM etc. and how they had effectively worked for pollution prevention and environmentimprovement will be discussed with supporting result data.
\end{abstract}

Key words: Environmental engineering, quality control, total quality management (TQM), ISO 9000, ISO14000, total productive maintenance, industrial pollution, Kaizen

\section{INTRODUCTION}

For 250 years from the beginning of $17^{\text {th }}$ century, Japan closed the country from outside foreign countries. In 1600, Japanese economy depended mostly on agriculture and not big, but not different too much from other countries in the world. But the industrial revolution in the Western world created many industrialized, rich countries after that. Japan was isolated from that and although there were 80 to 90 small iron mines and iron industry has began to have a factory system, craft industries are almost the only technological industries in those peaceful closed age.

After the Meiji Restoration in 1868, Japan imported western philosophy and technology quite vigorously and its economy was expanded rapidly by the industrialization. The remarkable performance was shown by the fact that the annual output grew 70 fold between 1885 and the end of 1999. This growth made possible the increase of national income per person 21 times and many developing countries followed this example of Japanese experience.

However, when Japan was defeated in World War II in 1945, most of the domestic manufacturing bases were destroyed and outside territories were lost, the nation's economy was almost totally paralyzed from the destruction, together with severe food shortage and skyrocketing inflation. Japan is an island country with very poor in natural resources and had to support a population of more than 80 million in its relatively small islands. Japanese people worked hard to rebuild the war-devastated economy, but it was in 1951 when the gross national products recovered its 1934-46 level and because of increase of population by returning people from outside, per capita GNP was regained only in 1954 its 1934-36 level, the biggest achieved so far.

Japan's economy continued to expand from 1950s to 1997 , with very rapid growth until 1978, when growth rates of gross domestic products are double digit with only one-year exception. After 1979, GDP still continued to grow, although only $1.0 \%$ to $2.6 \%$ in 1993-97. Figure 1 shows growth of GDP per capita between 1955 and $2000^{[1]}$.

Corresponding Author: $\quad$ Mohammed Matouq, Faculty of Engineering Technology, Chemical Engineering Department, AlBalqa Applied University, Amman, Jordan 


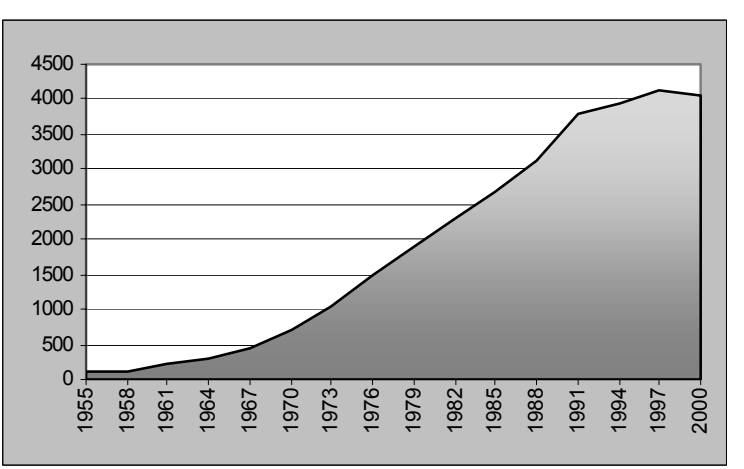

Fig. 1: GDP per capita of Japan, unit 1,000 Japanese yen

This rapid expansion of Japan's economy depended much on the vigorous investment of private industry in new plant and equipment with introduction of new technologies, which made Japanese industries more competitive on the world market, with new products, benefit of mass production and high productivity per worker. In addition, another remarkable factor was the availability of abundant labor forces with high level of education and Total Quality Control methodologies were successfully implemented by these labor forces with Everyone's Participation and helped to lead the economy a rapid growth.

In the meantime, Japanese economy suffered very much from pollution to environment and human being. In this paper, how the Total Quality Control methodologies and Everyone's Participation, which were initially targeted for improvement of quality and productivity, also contributed to reduce promptly the pollution by industries will be discussed.

\section{Industrial pollution}

Four big pollution law suits and local citizen participation: During the age of rapid economic growth, Japan found itself in severe environmental deterioration especially where big industry (mainly chemical) were located which had affected the quality of environment and had caused damage to citizens. Many of them were accused by local citizens and/or local medical doctors and citizens sued suspected polluters and local government to stop pollution and pay compensation for their damage. Four cases are popular as big kogai (pollution) suits ${ }^{[2]}$.

1. The minamata disease: In 1956, outbreak of a disease that attacks the central nervous system was reported in Minamata city. The cause was then unknown, but it was becoming clear to be related to heavy metals being discharged into the waters of Minamata bay by a plant of Chisso Corporation, a chemical manufacturer producing fertilizers and associated products.

After a long scientific researches and political debates, the government officially acknowledged that the cause was organic mercury from the plant and necessary measures to stop pollution and to compensate polluter with state assistance.

2. Itai-itai disease: In the late $1950 \mathrm{~s}$, a strange disease with suffering bone deformation and fractures arose in the Jintsu River Basin and named the Itai-Itai (ouch, ouch) from the extremely painful affliction. The cause was found out to be cadmium poisoning from an upstream lead and zinc mine. In 1971, district court ruled in the favor of plaintiffs, which was the first victory for victims of industrial pollution.

3. Air pollution in Yokkaichi: Yokkaichi City had a population of ca. 200,000 in 1960 and produced one fourth of petrochemical industry output in Japan. Two petrochemical complexes were launched in 1963-64 and consuming heavy oil with sulfer content of about 3 percent in those days, annual sulfer oxide emission to the air was estimated 130,000-140,000 tons. After compensation measures were introduced in 1970s, number of certified sufferers of air pollution in Yokkaichi district were totaled 1,738.

Reduction of air pollution: While some pollution above were caused by special chemicals, the source could be removed by stopping of operation, changing process and so on, however, removing of air pollution is more complicated and difficult. Sources of pollutants were not only heavy industry but also medium and small industries, cars and trucks and most of human activities including household. Countermeasures to reduce pollution are executive's investment and changing of raw material/fuels, engineers technology and everyone's participation implementing all measures to success.

\section{Quality control and everyone's participation}

Statistical quality control (SQC): Japan had exported miscellaneous goods to many countries in the world before World War II, but those "made in Japan" were rather popular as "cheap price, inferior quality". When Japan was suffering from poverty and famine after defeated in World War II, Japanese people found out that they had to export value-added products in order to raise their living standard, because Japan had not enough natural resources to support their population in a small island country. And they realized also that their product must have good quality to be accepted in export market.

Statistical Quality Control was introduced from the United States in around 1950. The history of statistics is not very long, for two or three centuries and most developments were in $20^{\text {th }}$ century. W. A. Stewhart of Bell Telephone Laboratory, U.S.A applied statistics to quality control in 1924, starting with a sketch of a modern control chart. And this methodology is developed in the U.S. by the name of Statistical Process Control (SPC). 
The base of statistical process control is a comparison of what is happening now with what happened previously. We build a model of how we think the process will perform and calculate control limits for the expected measurements of the output of the process. We collect data from the process and compare the data to the control limits. Data which fell outside of the control limits should be examined. Several techniques to investigate the products for defects were developed and widely applied in industries in the U.S.

Total quality management (TQM): The name Total Quality Control (TQC) has been widely used and very popular in Japan as well as in other countries, whose methodology mostly developed in Japan, however, in the course of innovating methodology and philosophy, a similar methodology called TQM was initiated. The Union of Japanese Scientists and Engineers (JUSE), an organization starting TQC promotion inviting Dr. W. E. Deming at first in 1950 and one of the most leading institution in this field ever since, changed the name of their methodology recently from TQC to TQM, considering that TQM, Total Quality Management, represents more properly what they are doing now.

W. Edward Deming and J. M. Juran, both from the U.S., created the ideas and methodologies of total quality control in the 1950s, but found no interest in their country. The Japanese commenced to integrate the concepts into their industrial base and adapted to almost all of manufacturing industries and other sectors of industry, business, government etc. The most distinguished characteristics to make this methodology a philosophy are the continuous effort for improvement and everyone's participation. Small group activities are widely organized by the name of QC circles and in manufacturing industries, for instances, decision to introduce TQC is by management, however, everyone concerned, middle management, engineers and other staff and laborers work for TQC as their own job. Everyone participate in improving quality of his or her products and of businesses, believing that improving of them is improving of himself or herself. The results were drastic improvement in quality of products in Japan.

The Union of Japanese Scientists and Engineers, JUSE, summarizes the methodology in "7 QC Tools", "7 New QC Tools" and "The QC Approach to Problem Solving" as follows ${ }^{[3]}$ :

\section{QC tools}

1. Pareto Diagrams: to get a handle on the real problem from among many

2. Cause and Effect Diagrams: to search out and organize all possible factors

3. Graphs: to make data visible to the eye

4. Check Sheets: to take down data simply and prevent inspection omissions
5. Histograms: to understand the form of a distribution and compare it to a standard

6. Scatter Diagrams: to find the correlation between a paired data

7. Control Chart: to investigate whether a process is stable or not

\section{New QC tools}

1. Relation Diagrams: to clarify complex problem by logical relation

2. Affinity Diagrams: to organize complex situations and identify problems

3. System Diagrams: to search systematically for the best way to achieve objectives

4. Matrix Diagrams: to clarify problems by multidimensional thinking

5. Matrix Data Analysis: to arrange data in a matrix diagram for easy analysis

6. PDPC Method: to determine a process for reaching the desired result

7. Arrow Diagrams: to represent the required operational relationships in network form to control scheduling

The QC approach to problem solving: The "Five Main Tasks" of Workplace Management and others. When many people are working with these concepts of TQM, pollution by industry became public. Everyone participating TQC and working for improvement of quality and productivity realized that reduction of pollution is one of improvement and took action utilizing TQC procedure.

Total productive maintenance (TPM): TPM, Total Productive Maintenance is a maintenance program concept by the name. The Japanese imported procedures of PM, Productive Maintenance from the U.S. and Japan Institute of Plant Maintenance (JIPM) developed TPM instructing and working with hundreds of Japanese companies. The history of starting TPM by JIPM is as follows ${ }^{[3]}$ :

In the 1950s and ' 60 s, Japan's process industry was in the midst of a rapid program of construction of productive plants and facilities. As this buildup proceeded, it grew increasingly clear that productivity and product quality in process industry were strongly affected by the condition of plants and facilities. To control these factors, techniques of plant maintenance were introduced from the U.S. At the heart of plant maintenance was Preventive Maintenance, which would later inspire a method called Productive Maintenance, developed at General Electric to improve productivity. Plant maintenance, along with its central principle of Preventive Maintenance, led to the formation of specializes maintenance organizations, establishment of plant maintenance systems and development of diagnostic technologies. Through activities to raise efficiency in maintenance work, plant maintenance 
provided a significant contribution to the evolution of the process industry. At the same time, however, these trends reinforced a division of labor between equipment operation and equipment maintenance. In effect, this caused equipment operators to become estranged from the equipment it was their task to operate.

Under these circumstances, TPM was first established for process industry, however, in the 1970s, JIPM introduced TPM to the fabrication and assembly industries.

The definition of TPM today by JIPM ${ }^{[4]}$ is:

1. TPM aims to create a corporate system that maximizes the efficiency of production system (overall efficiency improvement)

2. TPM creates systems for preventing the occurrence of all losses on the front line and is focused on the end product. This includes systems for realizing "zero accidents, zero defects and zero failures" in the entire life cycle of the production system

3. TPM is applied in all sectors, including the production, development and administration departments

4. TPM is based on the participation of all members, ranging from the top management to frontline employees

5. TPM achieves zero losses through overlapping small-group activities

TPM started with $5 \mathrm{~S}$ of activities. $5 \mathrm{~S}$ are five Japanese words starting with $\mathrm{s}$ and they have similar but a little different English translations also starting with s. They are seiri (sort), seiton (straighten), seiso (shine), seiketu (standardize) and shituke (sustain).

Among these 5S, seiso literally means cleaning and washing for shine and seiketsu also means cleanness. These are originally for better productivity and quality, but also for better working circumstances. Participants became aware soon that they should work both for less emission of hazardous material from their working circumstances and for manufacturing environmentally friendly products.

ISO 9000: ISO9000 Series of Standards are for quality management systems and quality assurance standards by International Organization for Standardization, first published in 1987. For most of Japanese organization concerned, TQM, TPM or something equivalent had been introduced and activities to guarantee their products were taken, however, it was necessary or better to get certification of ISO because some of their customers require or evaluate these certifications for their trade.

Many Japanese concerned found out the differences of ISO9000 from TQM, TPM were ISO9000 is rather management oriented and to be satisfied if products are within criteria. Systems originated in Japan are always aimed for improvement, as one of them is called KAIZEN, which means improvement in Japanese. They feel within criteria is not the assurance of quality.
In December 2000, revisions of ISO9000 were released and eight principles including "Involvement of people" and "Continual improvement" were published. With these revisions, the similar effects to pollution prevention like TQM, TPM are expected.

The role of $Q C$ and everyone's participation to prevent pollution: In most cases of industrial pollution, local people were suffering and accused suspected polluters and local medical doctors sometimes helped them, but often industry side did not agree the fact that they were polluters at first. Public Opinion Poll by Prime Minister's Office shows, in October 1973, 19.8\% of people answered economic development is more important while $49.7 \%$ of people answered environmental protection is more important ${ }^{[5]}$. Most of people in industry seemed to be in the group supporting economic growth.

However, those people also had to realize soon the fact that their economic activities cause serious damage to environment including direct damage to public health and made decisions. Management decided to raise fund to stop or improve their operation and engineers and other staff proposed and prepared for changing equipment, facilities and/or operations. And others inside the industry were waiting. Most of them were trained and implementing TQM, TPM and/or other methodology and all participants were working for improvement. When they realized reduction or stopping of pollution is necessary, it was a new target of their methodology and they started fighting against pollution.

Figure $2^{[6]}$ shows annual average of sulfur dioxide, $\mathrm{SO} 2$ concentration at 1,501 general air monitoring stations and 96 automobile emission monitoring stations from 1970 to 2002. Data of general stations show a sharp decrease in 1970s and steady decrease after 1980. These are by quick actions of industry in 70 s and by continuous efforts of all sectors concerned in 80s and after. In data of automobile emission, rather slow curve of decrease shows that technological innovations were needed for reduction, but with the improvement of products by new technologies and quality control, Japanese industry has achieved pretty good result.

Figure $3^{[7]}$ shows emission of SOx and NOx per KWh of electricity generation by thermal power generation plants in several industrial countries. Data of U.S.A. and Germany are at 1997, Canada, U.K. and France are at 1996 and Italy, 1995 and all of them from OECD. Data of Japan is at 2000 and by the Federation of Electric Power Companies, Japan. The bases of data may somewhat differ by country, however, difference of data from Japan are much better than those from other countries. Emission of SOx by Japanese was 0.23 $\mathrm{g} / \mathrm{KWh}$, only 10 percent of the best data from others and that of NOx, $0.28 \mathrm{~g} / \mathrm{KWh}$, was 31 percent of the same. 


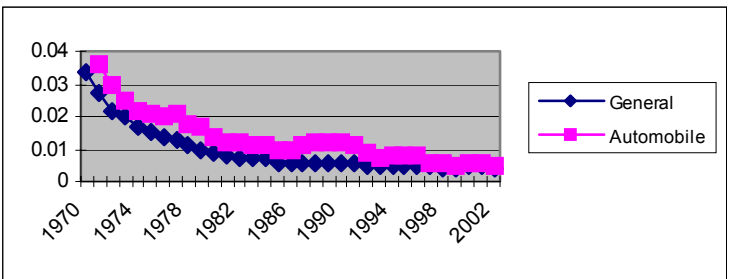

Fig. 2: Annual average of $\mathrm{SO}_{2}$ concentration in air, Japan

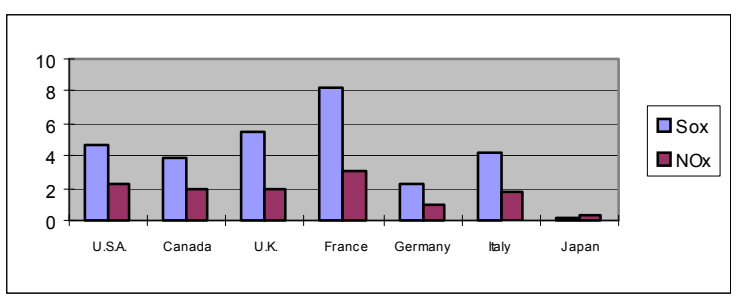

Fig. 3: Emission of SOx and NOx from thermal power plants Unit: $\mathrm{g} / \mathrm{KWh}$

One of the reasons to have achieved these good results is replacing resources of fuel to less sulfur origin, but there are other big factors, technology and investment of improving equipments and facilities and quality control to keep the operation continuously in good condition. Because technologies and investment are not much different among these industrial countries, one of the biggest reasons to have achieved this distinguished result is the skill of Quality Control and everyone's participation.
Industrial pollution in Japan was drastically reduced with help by Quality Control and Everyone's Participation, as shown by the data above of sulfur oxide emission as an example and most of Japanese products are made environmentally friendly from the same basis.

\section{REFERENCES}

1. Department of Statistics, Japanese Government.

2. Matouq, M. and K. Inoue, 2001. Japanese experience in the battle of air pollution prevention. 1st Intl. Chem. Engg. Conf., University of Jordan.

3. Hosotani, K., 1994. All About QC, JUSE Publications 1993, 1994.

4. Japan Institute of Plant Maintenance, 1998.

5. Imura, H., 1993. Air pollution control policies and changing attitudes of the public and industry. UNU Intl. Symp.

6. Ministry of the Environment, Japan.

7. The Federation of Electric Power Companies, Japan. 